\title{
FORMATION OF READING CULTURE IN THE UKRAINIAN SOCIETY: HISTORICAL ASPECT
}

\section{Bessarab A. O.}

\section{Introduction}

Nowdays, reading has acquired a qualitative new form due to the spreading of e-books and online media. Modern realities indicate that books change their place in the system of values and reading culture is declining due to the number of political, social and economic reasons, which leads to negative trends, related to the level of education and spirituality of society. Therefore, educational institutions, libraries, publishing houses have to find the best ways to solve this problem. Now the implementation of a New Ukrainian school has begun. The «Conceptual Basis of Secondary Education Reforming», in particular, emphasized: «Every school will have a modern library in its structure, which will become a resource center and a test site for pupils and teachers, will provide a free access to a quality electronic textbooks, encyclopedias, libraries, laboratories» ${ }^{1}$. All of the above determines the topicality of this research.

\section{History of reading and its study}

Reading as a way of communication has come a long way, and its evolution continues today. The development of science and technology is making own adjustments to this process. However, at all times the attitude to reading determines the level of society development. Accordingly, it draws attention of representatives of various science branches: bibliopsychology, pedagogy, history, philosophy, sociology, social communications, etc.

1 Нова українська школа. Концептуальні засади реформування середньої школи: документ пройшов громадські обговорення і ухвалений рішенням колегії мон 27.10.2016. C. 29. URL: http://mon.gov.ua/activity/ education/zagalna-serednya/ ua-sch-2016/ konczepcziya.html (дата звернення: 17.07.2019). 
The main areas of bibliopsychology research in the 1920s - 1930s:

- methodological problems of bibliopsychology;

- psychology of reader: types of readers' interests, «reader interest» and «reader require» concepts, main types of readers' interests, typology of readers based on the development of readers' interests, of social and class affiliation, of gender, age, constitutional and other features;

- psychology of reading: peculiarities of certain psychic processes and states of a person during reading (thinking, memory, attention, will, emotions and feelings), basic stages of reading (pre-reading, actual reading, «interest outside the book» stage), basic mechanisms of reading (perception, understanding and aquairing of the read) and some of their peculiarities, interrelation of the individual and social, emotional and rational, objective and subjective during the reading, problem of interaction between an author and a reader $2 ; 3 ; 4 ; 5 ; 6 ; 7$.

The researches of readers' interests in 1920s-1980s represent typology approach to their study. One of the most spread typology of readres' interests related to the social and class affiliation of readers.

For two decades (1965-1986), the «Book and Reading in the Life of Soviet Society» research project was carried out, which included a systematic study of reading and readers' orientations of basic social groups. Such researches as: «Soviet Reader» (1965-1967); «Book and Reading in the Life of Small Towns» (1969-1972); «Book and Reading in the Life of Soviet Village» (1973-1975) gave a comprehensive view of reading $8 ; 9 ; 10$. The project presents readers' preferences of different

\footnotetext{
${ }^{2}$ Арефьева Е. П. Пропаганда книги и руководство чтением в трудах Н. А. Рубакина. Книга. Исследования и материаль: сборник. Москва, 1966. Вып. 12. С. 93-112.

${ }^{3}$ Библиотека в контексте истории: тез. докл. и сообщ. науч. конф. Москва, 1995. 98 с.

${ }^{4}$ Бородина В. А. Взгляды Н. А. Рубакина на читательское развитие личности. Чтение в современном мире: опыт прошлого, взгляд в будущее: тез. докл. I Общенац. конгресса по чтению 18-21 авг. 1992 г. «Рубакинские чтения». Москва, 1992. С. 14.

5 Мархлевска Я. Программированное обучение научной информации на курсах по повышению квалификации инженеров. Подготовка потребителей информачии и изучение нужд потребителей: междунар. симпозиум. Бухарест, 1968. С. 261-272.

${ }^{6}$ Словарь библиотечных терминов. Москва, 1976. С. 80.

${ }^{7}$ Тихомирова И. И. О классификации читателей и дифференцированном руководстве чтением. Советское библиотековедение. 1978. № 6. С. 43-56.

${ }^{8}$ Книга и чтение в жизни небольших городов / Гос. б-ка СССР им. В. И. Ленина. Москва: Книга, 1973. 328 с.

${ }^{9}$ Коган В. З. Человек: информация, потребность, деятельность. Томск, 1991. 191 с.
} 
social groups considering specific of region; it contains a rich statistic data. The «Soviet Reader» research determines the basic directions and priorities of further studies; it specifies and refines the primary data. The large corpus of data resulting from the research allowed to outline the most typical genre and thematic preferrings of readers, the impact of age, education and nature of work on the quality of readers' preferences, as well as to trace the mutual influence of reading and mass media.

The «Dynamics of Reading and Readers' Demand in Mass Libraries» research (1975-1985) created a statistical basis for the separation of sociology of reading ${ }^{11}$. This research allowed to study the readers' interests, their scope, orientation, the influence on the nature of reading such a subjective factor as fashion, but reading was analysed as «selfsufficient and self-evident reality, capable of self-explaining of own characteristics» ${ }^{12}$.

The researches of the Russian State Library, Russian Scientific Library and the State Republican Youth Library are devoted actually to problems of culture of reading of this period; there are developed a number of methodological and bibliographic materials on the formation of reading culture ${ }^{13 ; 14 ; 15 ; 16 ; 17 ; 18 ; 19 ; 20}$. Attempts were made to develop a

${ }^{10}$ Столович Л. Н. Красота. Добро. Истина: Очерк истории эстетической аксиологии. Москва, 1994. 464 с.

11 Динамика чтения и читательского спроса в массовых библиотеках: сб. науч. Трудов / Гос. б-ка СССР им. В. И. Ленина. Москва, 1977. Вып. 2.78 с.

12 Дворкина М. Я. Культура чтения и информационная культура. Проблемь формирования культуры чтения: материалы Всерос. науч. конф. Тамбов, 1994. С. 11.

${ }_{13}^{13}$ Вальдгард С. Л. Очерки психологии читателя. Москва; Ленинград : Госиздат, 1931. $112 \mathrm{c}$.

14 Иениш Е. В. Библиографический поиск в научной работе: справ, пособ.путеводитель / под ред. И. К. Кирпичевой. Москва, 1982. 247 с.

${ }^{15}$ Кирпичева И. К. Пропаганда библиотечно-библиографических знаний в городских и областных библиотеках: метод. пособ. / Гос. публ. б-ка им. М. Е. Салтыкова-Щедрина. Ленинград, 1959. 148 с.

${ }^{16}$ Курзанова Н. И. Ценностное сознание молодежи: сущность, структура, тенденции развития: Социологический аспект: автореф. дис. ... канд. пед. наук. Москва, 1993. 22 с.

17 Куштанина Л. И. Информационная культура специалиста: гуманитарные проблемы. Мир библиотек сегодня: науч.-информ. сб. Москва, 1994. Вып. 1. С. 58-66.

${ }^{18}$ Павлова И. А. Библиотечный интерьер: требования и задачи. Научно-технические библиотеки. 1995. № 7. С. 48-57.

19 Рокицкая Э. Е. Профессиональное чтение как коммуникативный процесс. Психология чтения и проблемы типологии читателей. Ленинград, 1984. С. 92-93.

${ }^{20}$ Стельмах В. Д. Социология чтения: реальное и желаемое. Книга и чтение в зеркале сочиологии. Москва, 1990. С. 7-14. 
readers' typology on the basis of the level of reading culture, grounding on their actual social status, education level and age. In the structure of the reading culture the significant attention was payed to the issues of perception of texts (literary and scientific ones), as well as to the organization of reader's work. A recommendative bibliography was considered as a basis for the reading culture.

The issue of propaganda of library and bibliographic knowledge is covered in the «Library and Scientivic Information» research ${ }^{21}$ in multidimentional way, and during he study there were discovered channels of obtaining of information by readers-specialists, the tematics of the propaganda of library and bibliographic knowledge in libraries; there was established the estimate, suggestions of readers about the range of knowledge, expertise and skills, and forms of propaganda; there were considered the groups of readers, the most interested in the propaganda of library and bibliographic knowledge, and defined the most rational forms and methods of readers education.

In the early 1990s, new issues arose in the service of readers, related, in particular, to the obvious changes of social and demographic profiles of readers and their information needs: the impact of change of social status and education content on the level of reading culture; the impact of audio and video culture on the nature and orientation of reading; contradictions between computer literacy of some groups of readers and level of their reading culture, etc.

At the request of the "Kyivstar» company, the specialists of the «Gf Ukraine» company in the summer of 2013 conducted the «Reading of Books in Ukraine» research, which covered more than 1000 respondents all over the country. As the results showed, from September of 2006 to August of 2013 the amount of book buyers decreased from 42 to $30 \%$. Only $1 \%$ of responders specified the lack of money as the main reason for not reading books, and as the basic obstacles were pointed, in particular, low familiarity with Ukrainian authors and publishing houses, poor promotion of modern literature; low popularity of electronic books and weakness of the content selling

\footnotetext{
${ }^{21}$ Стоуне Э. Психопедагогика. Психологическая теория и практика обучения: пер. с англ. Москва, 1984. 472 с.
} 
systems, that would allow to increase the availability of modern literature for Ukrainians; many other ways to spend a free time at home, that require less effort, than reading books, etc.

With regard to findings of this research the following recommendations were formulated:

1. To promote ratings of modern literature, both Ukrainian and foreign (including translation ratings).

2. To enhance the books advertising and stimulate their discussion, in particular, on the Internet.

3. To spread electronic books by creation of online libraries and sales systems, using ever-wider fleet of smartphones and tablets.

4. To spread social advertising about the usefulness of reading for personal and career development, and about the need for parents to read for children and to rose in them an interest to books.

5. To create in the bookshops as friendly and comfortable atmosphere as possible.

6. To promote the book sales through catalogues.

7. To consider «critical» price ranges: for electronic books $30 \mathrm{UAH}$, for printed ones - $50 \mathrm{UAH}$ and $100 \mathrm{UAH}^{22}$.

Under studying some issues of history of reading, D. Ravinskyi emphasizes, that «the main problem, arising as related to the study of reading, is based on that statistic data do not reflect the real value of reading in full. But specifically they are the most accessible for a researcher. Traditional is to analyse the documentation of libraries and book shops, which is based on quantitative indicators... A variant of this statistical approach is a research, based on traditional questionnaire methods. It can be stated that such works constitute the "mainstream" of modern Western studies of reading, presented in such periodicals, as "Reading Today", "Reading Research", "Literacy", and in specialized periodicals of library community. ... However, the methological limitations of shuch an approach are obvious. It is very obvious for the researchers of history of reading, because it is the historical approach that

\footnotetext{
${ }^{22}$ Дослідження читання книжок в Україні : підготовлено компанією «GfK Ukraine» на замовлення компанії «Київстар» / Гліб Вишлінський, заступник директора GfK Ukraine. URL: http://www.gfk.ua/imperia/md/content/gfkukraine/reports/report_gfk_reading_pres.pdf (дата звернення: 17.07.2019).
} 
involvs a broad humanitarian perspective. The one analyzing Western works in the field of history of reading, which which have seen the world in recent decades, can easely note a tendency to shift away from the quantitative approach, the attempts to consider the reading phenomenon in the variety of its cultural values» ${ }^{23}$.

Australian historian Lyons Martin rightly notes, that «after all, history of reading is the study of norms and practices, that determine readers' reaction to what they have read» ${ }^{24}$.

J. Raven considers that the leitmotif of new studies of history of reading is a the thesis that readers' reaction to texts is determined not so much by the texts themselthes, than by social circumstances and, therefore, readres' reaction is a social phenomenon, which just partly depends on real qualities of a text. According to the scholar, the history of readers and the history of reading of recent years are determined by researches, aimed not so much at the establishing of number and types of readers, or at the detection of a literacy level, or at the defining of the most widely-read works, but rather at the study of readres' practices, nature of reading and experience of an individual reader ${ }^{25}$.

New approaches to the study of history of reading are related to the emergence of new theoretical interpretations od reading, first of all, M. de Serto, R. Chartier, «receptive aesthetics» school, etc.

French historian and sociologist R. Chartier ${ }^{26}$ traces the history of interaction of human-text interaction, describing, as a carrier's formation (scroll, code, computer screen) affects the perception of the one and the same text. R. Chartier emphasizes, that there were three book revolutions, every of which greatly changed the nature of reading and information perception. In VI century the book in the form of scroll were replaced by a code (a book, composed of bonded sheets). It was a

23 Равинский Д. История чтения: раздвигая границы исследовательского пространства. НЛО. 2010. № 102. URL: http://magazines.russ.ru/nlo/2010/102/ra27-pr.html (дата звернення: 17.07.2019).

${ }^{24}$ Lyons M. The history of Reading from Gutenberg to Gates. Th European Legacy. 1999. Vol. 4. № 5. P. 50-57.

${ }^{25}$ Raven J. New Reading Histories, Print Culture and the Identification of Change. Social History. 1998. Vol. 23. № 3. P. 268-287.

${ }^{26}$ Шартье Р. Читатель в постоянно меняющемся мире. Иностранная литература. 2009. № 7. C. 184-191. 
milestone: it become possible to make notes, flip through pages, use the content list, system of references, etc. The logic of material form was adapted by authors to the very structure of works: it was divided into separate parts, and the material was presented in a form of linear sequence.

With an appearance of a new device of information displaying - a computer screen - the written culture has got a new carrier. The usual ways of writing, spreading of the texts have changed, and therefore, a ways of reading too. To read an electronic book you have to abandon traditional habits and methods: form of an electronic book requires another organization of material. The modern readers, who read from a screen, in some degree is in a position of the ancient readers, but with one difference - they read a scroll, that is usually vertically scrolls and has guides, typical for a code, - indicants, list of content, etc.

Hypertext and hyper reading transform not only relations between an image, sound and text, which are connected in non-linear way, but relations between virtually infinite number of texts that have lost their clear outlines. Now the main role is played by the link concept, that is an operation, which is connecting different text units, which are allocated for reading purposes.

Thereby the electronic text places the very «book» concept in question. There emerges an infinity space, in which differences between genges, or groups of text are being erased: all the texts become moveable, open, and written products (electronic mail, data bases, web sites, books) obtain almost the same form. Electronic representation contributes to flexible combination of texts in logical constructions, grants a reader right to combine and split in parts the text units and give them new appearance at a reader's own direction. This is a real revolution in the text perception. For instance, the PocketBook team offers readers an extencive line of E Ink devices, which have a simple interface and support almost all popular text formats. Another significant contribution to readers culture formation is a leading project of ReadRate company. ReadRate related directly to electronic books of PocketBook, but its purpose is much wider: users can find various book ratings, get personal recommendations, and learn about reader's preferences of celebrities. On the ReadRate web site it is possible to create a reader's 
personal page, to discuss a favourite, or, contrariwise, a disputable book, to save an interesting quotation or make a list of literature which is planned to read in the nearest future. If the user does not forget to mark on own page favourite works and authors, then eventually the system can offer books, matching the reader's interests. Actually, every owner of a PocketBook reader with an Internet connnection can be a member of the «jury», which can give some book a start in life or, contrariwise, left it to «gather dust» in an electronic library.

The ReadRate project is related to Facebook, LinkedIn, Twitter, «Vkontakte» and «Odnoklasnyky» social nets - it is possible to enter the site using account of one of these popular social nets. It allows a user to look through friends' book preferences, to discuss books and literature events, to post reviews, to recommend something to read, to quote the most interesting lines in the text, as well as make selections of favourite books and mark works, which is planned to read in future. For 2019, the company plans to update the readers line, and deeper integration of all services in the united software solution - Android and iPhone applications, integration with the ReadRate.com service and Bookland.ru shop; launch a brand new PocketBook CAD Reader Flex device with a flexible 13,3" E Ink Mobius display which is a professional device for reading drawings, diagrams and voluminous technical documentations, able to replace by itself a load of various papers, which specialists have to take out to a remote site ${ }^{27}$. Holding a leading positions in the market, the company is one of the most influentive subjects of formation of readers' culture. This fact is proven by endless competitions and festivals, for which they are one of the biggest sponsors; prestigious awards and prizes, which they are constantly get; their intense activity in social nets; creation of own projects, which promoting books among the modern generation of Internet technologies.

The studying the mutual relations of a text and reading led to formation of certain theories. One of them is that a text exist is so far as a reader exists, who is able to read it and give it a sense.

27 Тенденции мирового рынка ридеров от PocketBook. URL: http://litra.info/news/Tendentsii-mirovogo-rynka-riderov-ot-PocketBook/ (дата обращения: 03.07.2019). 
Yu. Melentieva ${ }^{28}$ carried out a bibliological analisys of reading as a phenomenon. In particular, she also notes, that researchers defined in the Modern Age three revolutions in reading: 1) from the beginning of writing to XII-XIII centuries - monastery reading was replaced by scholastic one, when books began to be considered as a tool of intellectual activity; there was a change of a form of text presentation - a scroll was replaced by a code; 2) the second half of XVIII century - an intensive reading was replaced by an extensive one; 3) XX century electronic presentation of a text. Yu. Melentieva lists the main models of reading:

- humanistic - this is a «scholar reading» of the Renaissance. The essence of the model is in the «book wheel» (a device, allowing to keep on the bookstand and read several books at the same time, to make notes and marks, to compare texts) and «generalism copy-book» (purposed to copy out under a thematic principle and rubrics excerpts from the read texts, interesting facts, etc.), which often had turned into a source of new texts in itself. There were «professional» readers, hired by aristocrats;

- Christian. Has been formed during religious reformations of XVIXVII centuries. Protestantism was grounded on individual reading of Bible texts, Catholicism was based on sermons and Bible interpretation by priests. The model is rooted in certain prohibitions for reading, censorship, reading of permitted texts only. Every Church tried to make readers of own worchippers. Reading the Bible in the family circle, church, personally accompanied people all life long;

- university - identical to the «scholar reading», formed in XVIII century;

- peoples reading: originated in XIX century, when residents of almost all European countries got the opportunity to master reading skills.

In our opinion, today another one revolution in reading is taking place due to the development of science, namely AR-technoligies, or augmented reality technologies. «Live books» have great potential. Cross media applications, incliding audio and video plots, make a significant

28 Мелентьева Ю. П. Модели, практики и приемы чтения: эволюция во времени и пространстве. Библиотековедение. 2009. № 1. С. 59-63. 
contribution to formation of reading culture, facilitate and hasten the reading process due to the clarity of material representation. Furthermore, they cardinally change the way of reading, because the favourite characters become part of reality. The pioneer of an augmented reality book in Ukraine become the «Alice in Wonderland» by Live Animations publishing house. Print run of the special edition of the «Through the Looking-Glass and What Alice Found There» by Lewis Carroll was 350000 of copies, that together with the first part, the «Alice in Wonderland» reaches 715 000. In total the Little Hippo publishing house put on the market 4 globally known children's book: the «Little Red Riding Hood», «Three Little Pigs», «Velveteen Rabbit», «Goldilocks and the Three Bears». Their total print run is 250000 copies. In the coming years, the TaleAR project also will offer a series of children's books with augmented reality for children from 3 years of age, printed on a special cardboard with a special paint, certified and allowed to use by children in EU countries and Ukraine ${ }^{29}$.

$\mathrm{We}$ are inclined to support a position of $\mathrm{K}$. Heniieva, who distinguishes communication eras: 1) oral communication culturetransfer of individual experience, social norms, traditions and knowledge from lip to lip; 2) documentary (book) culture (since the first document records -III-IV millennium BC) - the emergence of the main institutes known to us: document centres, archives, libraries, publishing houses, print shops, book trade, news-magasine industry, etc.; 3) multimedia (electronic) culture - replacement of one-dimencional space perception by multi-dimencional one ${ }^{30}$.

The basic practices of reading go with transforming through all eras and revolutions of reading, namely: «reading aloud» and «reading silently».

Considering reading in historical dynamics, qualitative changes and consequences determined by them, Canadian psychologist G.-M. McLuen noted about the change of reading culture during the transition from one era to another: «Two cultures, or technologies, can, as astronomical

\footnotetext{
${ }^{29}$ TaleAR - книги з магією доповненої реальності. URL: https://biggggidea.com/project/ talear-knigi-z-magieyu-dopovneno-realnosti/ (дата звернення: 17.07.2019).

30 Гениева Е. Ю. Библиотека как центр межкультурной коммуникации. Москва: Российская политическая энциклопедия, 2008. С. 34-35.
} 
galaxies, pass through each other without collisions, but changing with that their configurations» ${ }^{31}$.

Nowadays, there is an acute problem of loss of interest in reading. A. Sokolov cites the results of social researches conducted by a group of scholars led by S. Plotnikov, who in 1990s divided the country's population into four categories: «1) who read almost constantly - about $20 \%$; 2) who read 2 and more books every month $-25 \%$; 3) who read $1-2$ books in six month $-35 \%$; 4) who do not read at all $-20 \%$. It turned out, that not all "intelligent" people are avid readers. Only a third of graduates read constantly»" ${ }^{32}$. The researchers made a conclusion, that the main trend of recent years is the loss of reading its exclusive role in the society and turning it, on the one hand, into a source of obtaining required information, and, on the other hand, into an entertainment medium. The data, published in 2000s, confirmed this conclusion: about $20 \%$ people do not read no books, neither magazines, and only $18 \%$ uselibrary services, mostly students. For modern youth the main communicative channel has for a long time been the Internet, and bibliophiles with «rudimentary intelligent readers' attitudes», are less each day. The author offers to see a mission of a modern public library in the «serving to self-civilization, contributing to formation of intellectuals of XXI century, who will need library funds and will be a generation of book culture bearers» ${ }^{33}$.

According to our survey results of pupils of 9-11 grades of Zaporizhzhia (Ukraine), conducted in 2016, the majority (72\%) have read $2-5$ books in the last three month; at the same time, the majority (40\%) did not buy any book. The most common is reading from the computer screen - it was an answer of $32,16 \%$ respondents ${ }^{34}$.

Ukrainian researcher $\mathrm{V}$. Teremko thoroughly considering a book, text and author in the strategy system of a publishing house, and reading - as

\footnotetext{
${ }^{31}$ Мак-Люен Г.-М. Галактика Гутенберга: Становлення людини друкованої книги / пер. 3 англ. А. А. Галушки, В. І. Постнікова. 3-тє вид. Київ: Ніка-Центр, 2011. С. 201.

32 Соколов А. В. Миссии и мутации библиотек: раздумья интеллигента-книжника. Библиотечное дело. 2009. № 14. С. 2-10.

33 Соколов А. В. Миссии и мутации библиотек: раздумья интеллигента-книжника. Библиотечное дело. 2009. № 14. С. 2-10.

34 Бессараб А. О. Соціально-комунікаційні технології формування інтересу до читання української книги: монографія. Запоріжжя: КПУ, 2016. С. 14.
} 
a field of self-realization of publisher strategies. He concludes that "modern challenges in the field of book-learning, reading and publishing venture can transform into a new dimension of opportunities with effective comprehension of realies and trends, as well as essece parameters of future, implementation of adaptative and groundbreaking strategic programs" ${ }^{\prime 35}$.

In sum, for today both world community and Ukrainian society have an urgent need in such strategic programs to increase the general level of culture and culture of reading in particular.

\section{Formation of reading culture of Ukrainian book in the information society with the help of social and communication technologies}

R. Pertsovska notes that in modern society three main levels of development of the reading culture are functioning: governmental, social, individual one, which, in its turn, at the same time are the basis of formation and qualitative indicators of the society culture ${ }^{36}$. To our opinion, the researcher left out of account the international level, and within the social one the organizational and family levels should be distinguished. Considering this and the results of our own researches, we can characterize the main levels of formation of the reader's culture in this way.

The international level is presented by UNESCO, the International Publishers Association (IPA), the International Booksellers Federation (IBF), the International Federation of Library Associations and Institutions (IFLA), etc. As a result of their collaboration, the «World Book Capital» project was implemented. As for Ukrainian books, in particular, the 37th session of the General Conference of UNESCO brought the 200th anniversary of the birth of Taras Shevchenko, the 150th anniversary of the birth of Pavlo Hrabovskyi, the 150th anniversary of the birth of Mykhailo Kotsiubynskyi, the 200th

35 Теремко В. Видавництво-ХХІ. Виклики і стратегії: монографія. Київ: Академвидав, 2012. C. 299.

36 Перцовская Р. Ф. Культура чтения в эпоху электронных технологий. Вестник библиотек Москвы. 2008. № 4. С. 7-10. 
anniversary of the birth of Mykola Verbytskyi to the calendar of commemorative dates of UNESCO.

In the context of our research, it is also noteworthy that UNESCO declared 2007 as the year of reading.

The governmental level is the State Committee for Television and Radio of Ukraine, the Ministry of Education and Science of Ukraine, the Ministry of Culture of Ukraine, the National Academy of Sciences, the Ukrainian Library Association, etc. In Ukraine, the formation of culture of reading of Ukrainian books at the governmental level is carried out in accordance with the Decree of the President of Ukraine «About Some Measures of State Support of Book Publishing Business and Popularization of Reading in Ukraine» dated June 19, 2013, No. 336/2013, and the Resolution of the Cabinet of Ministers of Ukraine dated February 24, 2016, No. 111-p, which approved the Concept of the state policy on the development of national publishing business and popularization of reading for the period until $2020^{37}$. According to the mentioned documents, the main executor is the State Committee for Television and Radio of Ukraine. In the context of this research, we should separately note the annual competition for the best presentation of the Ukrainian book in printed and electronic mass media, established in 2007 by the State Committee for Television and Radio of Ukraine in order to promote books of various subjects and popularization of reading ${ }^{38}$. The winners of this competition were mainly the state media. No less important is the «Best Book of Ukraine» All-Ukrainian contest.

The organizational level is represented by libraries, educational institutions, bookshops, publishing companies, publishers, media holdings, mass media editorial teams, public organizations, in particular the Forum of Publishers, the Center for Literary Education, PocketBook, etc.

37 Про схвалення Концепції державної політики щодо розвитку національної видавничої справи та популяризації читання на період до 2020 року: Розпорядження Кабінету Міністрів від 24.02.2016 № 111-p. URL: http://zakon5.rada.gov.ua/laws/ show/1112016-\%D1\%80 (дата звернення: 17.07.2019).

${ }^{38}$ Про проведення щорічного конкурсу на краще представлення української книги в друкованих та електронних засобах масової інформації: Наказ Державного комітету телебачення та радіомовлення України від 16.07.2007 №278. URL: http://zakon4.rada.gov.ua/ laws/show/z1121-07 (дата звернення: 17.07.2019). 
At the organizational level, the following events are carried out: creation of thematic programs, sections, movies; foundation and conducting of literary and book exhibitions, fairs, competitions, etc. Libraries and educational institutions organize poetry rings, literary tours, days of literary games, literary salons, evenings of readers' preferences, library gatherings, literary coffee houses, media performances, literary investigations, literary rendezvous, literary vernissages, literary sketches, etc. In particular, T. Yarova ${ }^{39}$ developed for the libraries a model of activity to overcome the crisis of children reading, which consists of five interconnected blocks:

- creation of a comfortable information environment;

- providing of the psychological support of the reader - «Don't be afraid, I am with you», in the basis of which is a facilitative communication, that is, the creation of a special atmosphere in interpersonal interaction, when the reader's personality is the main, and a librarian takes the position of assistant and helps to find answers to questions and learn skills;

- formation the image of positive leadership on the example of people who like to read - «Leaders are Always Readers» («Reading Person» photocollages, meetings with owners of home libraries, discussions about the role of a book and reading in the lives of prominent people);

- formation of the foundations of the informational culture - «We Read. We Know. We Can» (information boards, reminders for readers, bibliographic lists, «Drop Everything and Read», «For the Curious», «The Book Helps» indexes);

- implementation of the joint vigorous activity («Initiation to Readers», events within the All-Ukrainian day of libraries, month and weeks of books).

The family level includes such activities as family reading, reading with a child, participation in events organized by higher levels. Thus, within the book exhibitions and fairs, children's playgrounds are organized, for example, the Book Toloka in Zaporizhzhia annually

\footnotetext{
39 Ярова Т. Е. Подолання кризи дитячого читання через актуалізацію образу «людина, що читає». Шкільна бібліотека. 2009. № 10. С. 39-46.
} 
creates the «Knyholissia» («Book Forest») family space, that is the festival of children's literature.

The individual level is represented by individuals who are concerned with reading issue, and it includes the promotion of reading in private conversations, participation in events organized by higher levels. Here we have to note the role of the authors, who are both the initiators of the relevant events, and the participants of the events organized by others. Writers can be members of international and state institutions that work in the appropriate direction. To various extents, but necessarily they are present at all levels of the formation of reader's culture, because without authors, the actual reading would not exist.

Subjects of each level take part in events organized at higher levels, and in their activities turn to the same technologies, but apply them at different scales.

At all levels, the subjects of the formation of reading culture in the information society use the following social and communication technologies:

- education - the organization of raising the intellectual level and satisfying of the cognitive needs of individuals. Example: actually the Center for Literary Education provides non-formal education for those who want to become a writer, organizing lectures, trainings, etc. with the participation of famous authors;

- organization of leisure time - organization of recreation and leisure activities of individuals. Example: reading is one of the ways of spare time spending, such events as poetry rings, literary tours, days of literary game, literary salons, evenings of readers' preferences, library gatherings, literary coffee houses, etc. are aimed to make this leisure activity useful for personal development;

- information coverage (promotion). O. Kholod gives the following definition of this technology: «unpaid, completely voluntary form of personal informational influence on individuals in order to bring them information about the company, its activities and goods it produces» ${ }^{40}$. Example: transferring of information about the support for the works of a certain author, books of a particular publishing company face to face,

\footnotetext{
${ }^{40}$ Холод О. М. Комунікаційні технології: підручник. Київ, 2013. С. 5.
} 
while knowing that there will be no payment for it, it will not bring glory, and a positive perception is not guaranteed;

- public relations - task-oriented systematic public networking. One of these technologies is image building. Example: "A-BA-BA-HA-LAMA-HA» publishing house wins the professional competitions, takes part in book exhibitions, initiates TV programs to popularize reading, providing coverage of its activities in the media (publication of an interview with the director of the publishing house in the «Weekly Mirror. Ukraine» newspaper, presentation of own book in the morning program on the «Culture» channel, participation in the «Fairy Tale with Dad» project of the «PlusPlus» TV channel, etc.) in order to form a positive image of own publishing house and its products;

- advertising - informing consumers about the emergence of new organizations and types of goods and services. Example: during book exhibitions and fairs a publishing house hands out printed products with information about its publications and how it can be purchased.

$\mathrm{V}$. Teremko rightly notes that shaping a decision about a purchase begins with the need recognition. The stronger it is, the more chances that a customer leaves a bookstore with a bought title. Needs actualisation, the emergence of new ones can be caused by an ambitious self-raiting and own prospects, the development of the self-concept of personality. As a result, a person starts to think about own life, to see, to project own life perspective, to set new own goals, take more care for self-development, and this also creates the need in the knowledge concentrated in books. In modern world, human behavior depends heavily on advertising. Its content is aimed not only at future buyers and readers of publications, but also at persons who determine the need for books reading, initiate its search, make a decision on purchase ${ }^{41}$.

Press advertising belongs to the oldest kind of advertising as such. Of course, for all the time of its existence, which goes back centuries, press advertising not only gained popularity, but also produced a significant arsenal of forms and genres of advertising material presentation, which are worthy of particular attention.

\footnotetext{
${ }^{41}$ Теремко В. І. Видавничий маркетинг: навч. посібник. Київ, 2009. С. 207.
} 
Therefore, T. Bulakh in her "Advertising in the Publishing Business ${ }^{42}$ study guide characterizes its distinctive features.

Regarding the press advertising genres, it can be noted that almost all journalistic genres are used for advertising, and they can be divided into three groups: information genres (memorandum, interview, coverage, classified advertising); analytical (correspondence, article, digest, report, review, commentary); journalistic (sketch, essay) ones. The latter group is actively used in the preparation of PR-materials, materials with hidden advertising.

The main channels for information dissemination are the mass media (television, radio, press, internet media), social media, etc. Recently, such source of information, as social networks, including books ones, is gaining in popularity. As of 2014, S. Vodolazjka documents only two Ukrainian book social networks - they are Book.ua and Findbook.com.ua. This list can be expanded with network resources such as «Poetic Workshops» (maysterni.com) and «Poetry and the Author's Book of Ukraine» (poezia.org/ua).

Taking the abovementioned into account, we have developed the conceptual model of formation of culture of reading the Ukrainian book in the information society, which includes subjects of different levels (international level, governmental, organizational, family, individual one), measures (establishment of the World Book and Copyright Day, establishment and implementation of literary and book competitions and exhibitions, fairs, creation of thematic programs, sections, movies; family reading, reading with a child, promotion of reading in private conversations, etc.), technologies (education, organization of leisure time, information coverage (promotion), publc relations, advertising, etc.), channels (mass media, social media, etc.) and the object of influence, that is readers (fig. 1).

\footnotetext{
${ }^{42}$ Булах Т. Д. Реклама у видавничій справі: навч. посібник. Харків, 2011. 224 с.
} 


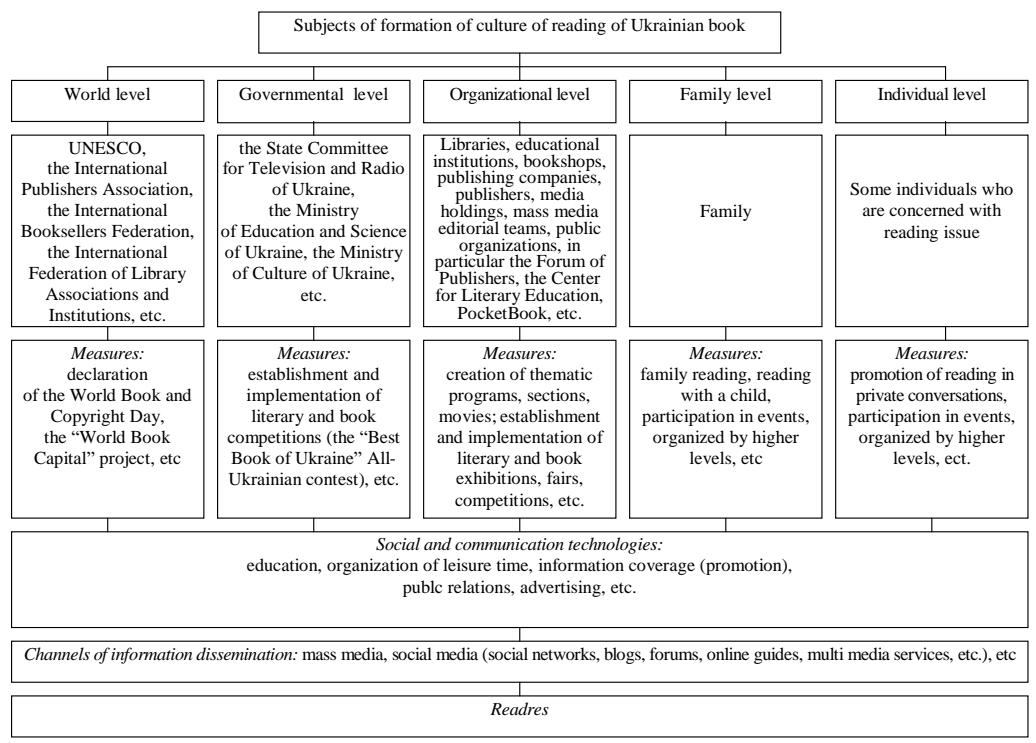

Fig. 1. Conceptual model of formation of culture of reading Ukrainian books in the information society by means of social and communication technologies

\section{CONCLUSIONS}

Reading as a way of communication has gone a long way, and its evolution continues. The development of science and technology adjusts this process. However, at all times, the attitude to reading determines the level of society development.

The main revolutions in reading and its culture in the the Modern Age in Europe are noted: 1) from the beginning of writing to XIIXIII centuries - a change of a form of text presentation, namely a scroll was replaced by a code; 2) the second half of XVIII century - an intensive reading was replaced by an extensive one; 3) XX century electronic presentation of a text; it is offered to allocate another one revolution in reading, which is taking place today and related to the spread of augmented reality technologies.

There are the following levels of development of culture of reading in modern society: international, governmental, organisational, family, individual, which, in its turn, is in the same time the ground for 
formation and qualitative indicies of society culture. The section of the monograph proposes a conceptual model of the formation of culture of reading of Ukrainian books in the information society, which includes subjects of different levels (international, governmental, organizational, family, individual), measures (establishment of the World Book and Copyright Day, establishment and implementation of literary and book competitions and exhibitions, fairs; creation of thematic programs, sections, movies; family reading, reading with a child, promotion of reading in private conversations, etc.), technologies (education, organization of leisure time, information coverage (promotion), public relations, advertising, etc.), channels (mass media, social media, etc.) and the object of influence, that is readers.

\section{SUMMARY}

The main revolutions in reading and its culture in the Modern Age in Europe are noted: 1) from the beginning of writing to XIIXIII centuries - a change of a form of text presentation, namely a scroll was replaced by a code; 2) the second half of XVIII century - an intensive reading was replaced by an extensive one; 3) XX century electronic presentation of a text; it is offered to allocate another one revolution in reading, which is taking place today and related to the spread of augmented reality technologies. The conceptual model of formation of culture of reading of Ukrainian book in the information society is offered, which includes the subjects of different levels (international, governmental, organisational, family, individual), measures (establishment of the World Book and Copyright Day, establishment and implementation of literary and book competitions and exhibitions, fairs, creation of thematic programs, sections, movies, family reading, reading with a child, promotion of reading in private conversations, etc.), technologies (education, organization of leisure time, information coverage (promotion), public relations, advertising, etc.), channels (mass media, social media, etc.) and object of influence, that is readers. 


\section{REFERENCES}

1. Арефьева Е. П. Пропаганда книги и руководство чтением в трудах Н. А. Рубакина. Книга. Исследования и материаль: сборник. Москва, 1966. Вып. 12. С. 93-112.

2. Бессараб А. О. Соціально-комунікаційні технології формування інтересу до читання української книги: монографія. Запоріжжя: КПУ, 2016. 360 с.

3. Библиотека в контексте истории: тез. докл. и сообщ. науч. конф. Москва, 1995.98 с.

4. Бородина В. А. Взгляды Н. А. Рубакина на читательское развитие личности. Чтение в современном мире: опыт прошлого, взгляд в будущее: тез. докл. І Общенац. конгресса по чтению 18-21 авг. 1992 г. «Рубакинские чтения». Москва, 1992. С. 14.

5. Булах Т. Д. Реклама у видавничій справі: навч. посібник. Харків, 2011.224 c.

6. Гениева Е. Ю. Библиотека как центр межкультурной коммуникации. Москва: Российская политическая энциклопедия, 2008. 208 c.

7. Дворкина М. Я. Культура чтения и информационная культура. Проблемь формирования культуры чтения: материалы Всерос. науч. конф. Тамбов, 1994. С. 11-13.

8. Динамика чтения и читательского спроса в массовых библиотеках: сб. науч. трудов / Гос. б-ка СССР им. В. И. Ленина. Москва, 1977. Вып. 2.78 с.

9. Дослідження читання книжок в Україні : підготовлено компанією «GfK Ukraine» на замовлення компанії «Київстар» / Гліб Вишлінський, заступник директора GfK Ukraine. URL: http://www.gfk.ua/imperia/md/content/gfkukraine/reports/report_gfk_rea ding_pres.pdf (дата звернення: 17.07.2019).

10.Иениш Е. В. Библиографический поиск в научной работе: справ, пособ.-путеводитель / под ред. И. К. Кирпичевой. Москва, 1982. $247 \mathrm{c.}$

11.Кирпичева И. К. Пропаганда библиотечнобиблиографических знаний в городских и областных библиотеках: метод. пособ. / Гос. публ. б-ка им. М. Е. Салтыкова-Щедрина. Ленинград, 1959. 148 с. 
12. Книга и чтение в жизни небольших городов / Гос. б-ка СССР им. В. И. Ленина. Москва : Книга, 1973. 328 с.

13. Коган В. 3. Человек: информация, потребность, деятельность. Томск, 1991. $191 \mathrm{c}$.

14. Курзанова Н. И. Ценностное сознание молодежи: сущность, структура, тенденции развития: Социологический аспект: автореф. дис. ... канд. пед. наук. Москва, 1993. 22 с.

15. Куштанина Л. И. Информационная культура специалиста: гуманитарные проблемы. Мир библиотек сегодня: науч.-информ. сб. Москва, 1994. Вып. 1. С. 58-66.

16. Мак-Люен Г.-М. Галактика Гутенберга: Становлення людини друкованої книги / пер. 3 англ. А. А. Галушки, В. І. Постнікова. 3-тє вид. Київ: Ніка-Центр, 2011. 392 с.

17. Мархлевска Я. Программированное обучение научной информации на курсах по повышению квалификации инженеров. Подготовка потребителей информации и изучение нужд потребителей: междунар. симпозиум. Бухарест, 1968. С. 261-272.

18. Мелентьева Ю.П. Модели, практики и приемы чтения: эволюция во времени и пространстве. Библиотековедение. 2009. № 1. С. 59-63.

19.Нова українська школа. Концептуальні засади реформування середньої школи: документ пройшов громадські обговорення i ухвалений рішенням колегії мон 27.10.2016. С. 29. URL: http://mon.gov.ua/activity/ education/zagalna-serednya/ ua-sch-2016/ konczepcziya.html (дата звернення: 17.07.2019).

20. Павлова И. А. Библиотечный интерьер: требования и задачи. Научно-технические библиотеки. 1995. № 7. С. 48-57.

21.Перцовская Р. Ф. Культура чтения в эпоху электронных технологий. Вестник библиотек Москвы. 2008. № 4. С. 7-10.

22. Про проведення щорічного конкурсу на краще представлення української книги в друкованих та електронних засобах масової інформації: Наказ Державного комітету телебачення та радіомовлення України від 16.07.2007 № 278. URL: http://zakon4.rada.gov.ua/ laws/show/z1121-07 (дата звернення: 17.07.2019). 
23.Про схвалення Концепції державної політики щодо розвитку національної видавничої справи та популяризації читання на період до 2020 року: Розпорядження Кабінету Міністрів від 24.02.2016 № 111-p. URL: http://zakon5.rada.gov.ua/laws/show/111-2016$\%$ D1\%80 (дата звернення: 17.07.2019).

24.Равинский Д. История чтения: раздвигая границы исследовательского пространства. НЛО. 2010. № 102. URL: http://magazines.russ.ru/nlo/2010/102/ra27-pr.html (дата звернення: 17.07.2019).

25. Рокицкая Э. Е. Профессиональное чтение как коммуникативный процесс. Психология чтения и проблемь типологии читателей. Ленинград, 1984. С. 92-93.

26.Словарь библиотечных терминов. Москва, 1976. С. 80.

27.Соколов А. В. Миссии и мутации библиотек: раздумья интеллигента-книжника. Библиотечное дело. 2009. № 14. С. 2-10.

28. Стельмах В. Д. Социология чтения: реальное и желаемое. Книга и чтение в зеркале сочиологии. Москва, 1990. С. 7-14.

29. Столович Л. Н. Красота. Добро. Истина: Очерк истории эстетической аксиологии. Москва, 1994. 464 с.

30.Стоуне Э. Психопедагогика. Психологическая теория и практика обучения: пер. с англ. Москва, 1984. 472 с.

31.Тенденции мирового рынка ридеров от PocketBook. URL: http://lit-ra.info/news/Tendentsii-mirovogo-rynka-riderov-otPocketBook/ (дата обращения: 03.07.2019).

32. Теремко В. Видавництво-XXI. Виклики i стратегії: монографія. Київ: Академвидав, 2012. 328 с.

33. Теремко В. І. Видавничий маркетинг: навч. посібник. Київ, 2009. 272 c.

34. Тихомирова И. И. О классификации читателей и дифференцированном руководстве чтением. Советское библиотековедение. 1978. № 6. С. 43-56.

35. Холод О. М. Комунікаційні технології: підручник. Київ, 2013. 212 c.

36.Шартье Р. Читатель в постоянно меняющемся мире. Иностранная литература. 2009. № 7. С. 184-191. 
37.Ярова Т.Е. Подолання кризи дитячого читання через актуалізацію образу «людина, що читає». Шкільна бібліотека. 2009. № 10. C. 39-46.

38. Lyons M. The history of Reading from Gutenberg to Gates. Th European Legacy. 1999. Vol. 4. № 5. P. 50-57.

39. Raven J. New Reading Histories, Print Culture and the Identification of Change. Social History. 1998. Vol. 23. № 3. P. 268-287.

40.TaleAR - книги 3 магією доповненої реальності. URL: https://biggggidea.com/project/talear-knigi-z-magieyu-dopovnenorealnosti/ (дата звернення: 17.07.2019).

\section{Information about the author: Bessarab A. O.,}

Doctor of Science in Social Communications, Associate Professor, Professor at the Special Pedagogy and Special Psychology Department, Municipal Institution of Higher Education «Khortytsia National Educational Rehabilitation Academy» 59, Science town str., Zaporizhia, 69017, Ukraine; Professor at the Journalism and Ukrainian Philology Department, Classical Private University 70b, Zhukovskoho str., Zaporizhia, 69002, Ukraine 